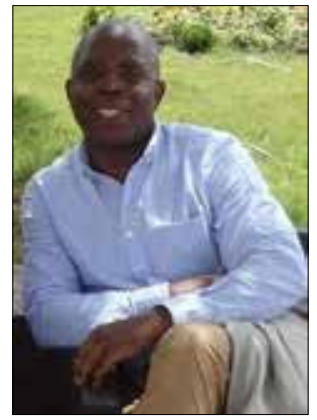

Aloba Leo Tosin

УДК 629.584

\title{
SYNTHESIS OF INTELLIGENT AUTOMATIC CONTROL SYSTEM OF AN AUTONOMOUS UNDERWATER VEHICLE AS A GROUP AGENT
}

\section{СИНТЕЗ ІНТЕЛЕКТУАЛЬНОЇ СИСТЕМИ АВТОМАТИЧНОГО КЕРУВАННЯ АВТОНОМНИМ ПІДВОДНИМ АПАРАТОМ ЯК АГЕНТОМ ГРУПИ}

DOI https:// doi.org/10.15589/smi2019.1(11).9

\section{Aloba Leo Tosin}

\author{
Алоба Лео Тосин, викладач \\ alobat@gmail.com \\ ORCID: 0000-0002-0509-8129
}

\section{Admiral Makarov National University of Shipbuilding, Mykolaiv \\ Наџіональний університет кораблебудування імені адмірала Макарова, м. Миколаїв}

\begin{abstract}
There are navigation problems when performing operations of autonomous underwater vehicles (AUVs) groups, and this article focuses on the effectiveness of controlling the coordinated motion of AUVs during operations in unknown environments with uncertainty to make operations more reliable and less goal redundant, making the AUVs operate in a coordinated motion. One of the main problems of AUVs group navigation is the collision with neighboring vehicles due to the uncertainty that arises during AUV group navigation. At the same time, improvement was required and a highly effective adaptive intelligent autonomous control system in the group transition (ACS GT) mode of a single AUV motion, as an agent that represents all members of the group, was synthesized. An example of a typical functioning AUV scheme with respect to the neighboring AUVs in a specific mission, such as surveying, tracking and search for sunken objects, is provided. The vehicles are controlled only in the horizontal plane and maneuver. The AUVs coordinated motion acting as a group to perform a specific task under conditions of underwater environment uncertainties, taking into account the nonholonomic characteristics of the AUVs, has become an important problem, since they represent significant problems for effective operations of the AUVs groups. A block diagram of fuzzy logic algorithm of the navigation environment situation modeling for a single AUV as a group agent is provided. Intelligent ACS GT is presented in three blocks - a Navigation Situation Model (NSM) in the immediate vicinity of the vehicle, a Navigation Threat Identifier (NTI) block, for detected navigation threat identification and, in fact, the ACS block of the individual AUV. The synthesis of the blocks is based on fuzzy logic system, which consists of precise (accurate) inputs, precise outputs and fuzzy rules. A synthesis was proposed to determine the distances between the vehicles and the derived distances, thus tuning the system and maneuvering to avoid collisions between the neighboring vehicles during operations.
\end{abstract}

Key words: autonomous underwater vehicle, group control, adhesion, cohesion, intelligent control system.

Анотація. Існують проблеми навігації при виконанні операцій груп автономних ненаселених підводних апаратів (АНПА). Ця стаття присвячена ефективності керування узгодженого руху АНПА при операціях у невідомих середовищах 3 невизначеністю для створення більш надійних і менш цілеспрямованих надлишкових операцій, спрямованих на те, щоб допомагати АНПА працювати в узгодженому русі. Однією з основних проблем навігації групи АНПА є зіткнення із сусідніми апаратами через невизначеність, що виникає під час навігації групи АНПА. При цьому вимагала вдосконалення і була синтезована високоефективна адаптивна інтелектуальна система автоматичного керування в режимі групового переходу (САК-ГП) рухом одиночного АНПА як агента, який представляє всіх членів групи. Наведено приклад типової функціонуючої схеми АНПА відносно сусідніх АНПА в певних місіях, таких як обстеження, відстеження і пошук затонулих об'єктів. Апарати керуються тільки в горизонтальній площині й маневрі. Узгоджений рух АНПА, що діють як група для виконання певного завдання в умовах невизначеностей підводного середовища з урахуванням неголономних характеристик АНПА, став важливою проблемою, оскільки становить значні складнощі для ефективних операцій груп АНПА. Запропоновано блок-схему алгоритму нечіткої логіки блока моделювання навігаційної обстановки для одиночного АНПА як агента групи. Інтелектуальну САК-ГП подано в складі трьох таких блоків: блока моделювання навігаційної 
обстановки в безпосередній близькості від апарата, блока ідентифікації виявлених навігаційних загроз i блока САК одиночним АНПА. Синтез блоків заснований на системі нечіткої логіки, яка складається 3 точних входів, точних виходів і нечітких правил. Був запропонований синтез для визначення відстаней між апаратами і похідними відстаней, щоб таким чином налаштовувати систему і маневрувати 3 уникненням зіткнень між сусідніми апаратами під час операцій. Інтелектуальний контролер нечіткої логіки може бути реалізований в інтелектуальній системі керування апаратами в групі для ефективної операції з узгодженим груповим рухом, що забезпечує процеси навігації АНПА з алгоритмами, адгезією і когезією в невідомих підводних середовищах з невизначеностями.

Ключові слова: автономний ненаселений підводний апарат, групове керування, адгезія, когезія, інтелектуальна система керування.

\section{References}

[1] Ioseba, Tena (2018). The Advancing Technology of AUVs. A View of the Autonomous Underwater Vehicle Market. Hydro International. Retrieved from https:/www.hydro-international.com/content/article/the-advancing-technologyof-auvs.

[2] Slămnoiu, G., Radu, O., Roşca, V., Pascu, C., Surdu, G., Curcă, E., Damian, R. G. \& Rădulescu, A. (2017). Efficient Use of AUVs in the Maritime Environment. International Conference on Innovative Research - Icir Euroinvent. Retrieved from http://iopscience.iop.org/article/10.1088/1757-899X/209/1/012098/pdf.

[3] Yeun-Soo, Jung, Kong-Woo, Lee, Seong-Yong, Lee, Myoung, Hwan \& Choi Beom-Hee, Lee (2009). An efficient underwater coverage method for multi-AUV with sea current disturbances. International Journal of Control, Automation and Systems, Vol. 7, 4, 615-629. Retrieved from https://ink.springer.com/article/10.1007/s12555-009-0412-4.

[4] Zereik, Enrica, Bibuli, Marco, Miskovic, Nikola, \& Ridao, Pere (2018). Challenges and future trends in marine robotics. Annual Reviews in Control, 1-19. doi: 10.1016/j.arcontrol.2018.10.002. Retrieved from https://www.researchgate.net/publication/328255241_Challenges_and_future_trends_in_marine_robotics.

[5] Fiorelli, E, Leonard, N. E., \& Bhatta, P. (2006). Multi-AUV control and adaptive sampling in Monterey Bay. IEEE Journal of Oceanic Engineering, 31 (4), 935-948.

[6] Yoon, S., \& Qiao, C. M. (2011). Cooperative Search and Survey Using Autonomous Underwater Vehicles. IEEE Transactions on Parallel and Distributed Systems, 22 (3), 364-379.

[7] Dapeng, Jiang, \& Bin, He (2014). Realistic Cooperative Control Mechanism of Multiple AUVs. Proceedings of the 33rd Chinese Control Conference / July 28-30, 2014, 1395-1400.

[8] Benjamin, Michael R., Schmidt, Henrik, Newman, Paul M., \& Leonard, John J. (2010). Nested Autonomy for Unmanned Marine Vehicles with MOOS-IvP. Retrieved from http://140.117.95.8/teacher/PUB/conference/Abstract Schmidt.pdf.

[9] Rohou, Simon (2016). An Overview of the MOOS-IvP Middleware. Abstract for the SHARC conference, 1-7.

[10] Bikramaditya, Das, Bidyadhar, Subudhi \& Bibhuti, Bhusan Pati (2016). Co-operative control of a team of autonomous underwater vehicles in an obstacle-rich environment. Journal of marine engineering \& technology, Vol. 15, 3, 135-151. https://doi.org/10.1080/20464177.2016.1247636.

[11] Omrane, Hajer, Masmoudi, Mohamed Slim, \& Masmoud, Mohamed (2016). Fuzzy Logic Based Control for Autonomous Mobile Robot Navigation. http://dx.doi.org/10.1155/2016/9548482.

[12] Almasri, Marwah, Elleithy, Khaled, \& Alajlan, Abrar (2016). Sensor Fusion Based Model for Collision Free Mobile Robot Navigation. Sensors (Basel), 24. doi:10.3390/s16010024. Retrieved from http://www.mdpi.com/1424$8220 / 16 / 1 / 24$.

[13] Elmokadem, Taha, Zribi, Mohamed, \& Youcef-Toumi, Kamal (2017). Terminal sliding mode control for the trajectory tracking of underactuated. Autonomous Underwater Vehicles, Vol. 129, 1 January 2017, 613-625. https://doi. org/10.1016/j.oceaneng.2016.10.032.

[14] Hai, Huang, Guocheng, Zhang, Hongde, Qing, \& Zexing, Zhou (2017). Autonomous underwater vehicle precise motion control for target following with model uncertainty. International Journal of Advanced Robotic Systems, 1-11. doi: $10.1177 / 1729881417719808$.

[15] Omrane, Hajer, Masmoudi, Mohamed Slim, \& Masmoudi, Mohamed (2016). Fuzzy Logic Based Control for Autonomous Mobile Robot Navigation. Comput Intell Neurosci, 1-10. Retrieved from https://www.ncbi.nlm.nih.gov/ pmc/articles/PMC5027372/.

[16] Pandeya, Anish, Kumarb, Saroj, Pandeya, Krishna Kant, \& Parhia, Dayal R. (2016). Mobile robot navigation in unknown static environments using ANFIS controller. Perspectives in Science, 8, 421-423. Retrieved from https://core.ac.uk/download/pdf/81931273.pdf.

[17] Distance Keeping for Underwater Vehicles - Tuning Kalman Filters Using Self-Oscillations. Retrieved from https://bib.irb.hr/datoteka/412520.Miskovic_et_al_OCEANS09_final_paper.pdf.

[18] Cain, C., \& Leonessa, A. (2016). Validation of Underwater Sensor Package Using Feature Based SLAM. Sensors, 16 (3), 1-29. https://doi.org/10.3390/s16030380. 
[19] Algabri, M., Mathkour, H., Ramdane, H., \& Alsulaiman, M. (2015). Comparative Study of Soft Computing Techniques for Mobile Robot Navigation in an Unknown Environment. Computers in Human Behavior, 50, 42-56. Retrieved from https://dl.acm.org/citation.cfm?id=2798785.

[20] Omrane, H., Masmoudi, M. S., \& Masmoudi, M. (2016). Fuzzy logic based control for autonomous mobile robot navigation. Computational Intelligence and Neuroscience, 1-10. doi:10.1155/2016/9548482.

[21] Burunina, Zhanna Yu., Aloba, Leo T., \& Hrudinina, Hanna S. (2018). Mathematical modeling of the automatic control system for an autonomous underwater vehicle as a group agent. Shipbuilding and Marine Infrastructure, 1 (9), 29-35. Retrieved from http://smi.nuos.mk.ua/article/view/142677/140183.

Problem statement. In many applications, a team of vehicles is more robust and can perform operation better than a single vehicle. Vehicles with lower performance or malfunctions can cause the collapse of the whole group. Considering these issues, the degree of autonomy of each AUV in the group should be increased and relatively less dependent on the characteristics of other vehicles in the group.

There are research efforts to make AUV groups of more applicable in underwater operations.

Therefore, at present, the actual applied scientific task of automation control of a separate AUV is the synthesis of an intelligent automatic control system for a group transition mode (ACS-GT) which eliminates the collisions between the neighboring AUVs or reduces the excessive increase in the distances between them which can cause the threat of the communication disappearance and the collapse of the group which makes the group perform operations in an accident-free environment.

Latest research and publications analysis. AUVs are becoming an increasingly important tool for maritime researches, search, offshore exploration, surveys, national defense and other important tasks $[1 ; 2]$ as they become more inexpensive "tasks made easy" applications in recent years.

The AUV team is more advantageous in operations in many respects than the use of one AUV, for example, in commercial applications, for mine defense and rapid environmental assessment in military operations at sea [3].

In modern scientific literature, the problem of AUV navigation is divided between global navigation, which is associated with the path creation that leads the vehicle to a given point in the underwater space, and local navigation, which is subordinate to the global navigation and ensures AUV trouble-free motion.

The development of autonomous robotic navigation methods is one of the main areas of underwater robotics [4]. Recent progress in underwater vehicle technology and acoustic communication has made it more practical than ever before in coordinated control of multiple autonomous underwater vehicles (MAUV). The teams of AUVs can consist of functionally different vehicles (heterogeneous), which may differ in their cruising speeds and ranges of hydroacoustic communication channels. Robustness, versatility and better performance are the advantages offered by multiple autonomous underwater vehicles (MAUV) over a single AUV in different tasks $[5 ; 6]$.

In [7; 8], MOOS (Mission Oriented Operating Suite, a middleware system for robotic platforms) based on publish-subscribe architecture was applied to coordinate AUV group control system for solving search operations. The IvP Helm (interval programming - a technique for representing and solving multi-objective optimization problems) is the primary component of an additional set of capabilities implemented to form MOOS-IvP modules for providing autonomy on robotic (with heterogeneous) platforms [9]. The IvP model was used to solve the problem of behavior coordination in behavior-based control strategy applied to MAUV system coordination. In [2], the optimal use for the AUVs in the maritime environment was established.

Recently, modern approaches to control fuzzy logic have been proposed, since this method provides a high degree of stability and resistance to interference $[4 ; 10]$. Approaches to fuzzy navigation in dynamic environments follow either the classical paradigm or the behavioral paradigm [11]. In both paradigms, the vehicle "reaction" is defined by a set of rules that describe the priorities of navigation.

In [12], a model based on multi-sensor fusion was also proposed to prevent collisions and track a given trajectory of the mobile robot. These methods have successfully reduced time and energy consumption.

Fuzzy controllers modeling with a sliding mode for AUVs without a system model was proposed in [13; 14] and the results of an AUV experiment using a fuzzy control law with a sliding mode was presented. The authors in [15] used fuzzy logic and visual sensors to avoid obstacles and movement of the direction of the robot to its target.

One of the main advantages of this method is a high degree of stability and immunity from external disturbances. Compared with other control methods, a fuzzy logic controller has the highest degree of freedom in setting parameters, and simple mathematical calculation is required [16].

In addition to the advantages of various research results and proposed models, there are also disadvantages. During missions, the coordinated mission provisions for the AUV security during the AUV group mission are not provided. During the mission, AUVs may be too close together and end up colliding, which may cause problems for the AUV team. In addition, there is a possibility that the AUV will move too far from the working areas of the AUV group and thereby lose contact and adversely affect the mission.

In this research, these problems will be considered by making the synthesis of the intelligent AUV ACS of a coordinated motion in the group transition of a safe mission. Attention is paid to the integration (fusion) of mul- 
tisensory information of rangefinders for the development of environmental sensors (ES) and the navigation environment (situation) modeling block for the vehicles to achieve best results.

The development of highly effective ACS for AUV motion was created to overcome modern challenges in the research of marine spaces. Therefore, intelligent ACS-GT for AUV motion must be adaptive.

The article aim is to synthesize the intelligent automatic control system of a single AUV as an agent of a group of underwater robotic vehicles moving in close proximity to each other in the group transition mode.

To achieve this goal in the article, it is necessary to solve the following tasks:

- to create a fuzzy logic algorithm block diagram for modeling the navigation environment for a single AUV as a group agent;

- to synthesize the navigation situation modeling block of a single AUV (agent);

- to synthesize the generalized automatic motion control algorithm of a single AUV in the group transition mode.

Methods, object and subject of research. Methods of research. During the research were used: method of theoretical analysis of the existing automatic control methods, the method of fuzzy logic and the numerical solution of differential equations, method of set theory. The methods of mathematical modeling were also used, using the automation tools of mathematical and engineering calculations in MATLAB (Simulink) environments.

Method of mathematical simulation modeling using, tools for mathematical and engineering automation calculations in MATLAB/Simulink environment.

Object of research - intelligent ACS of motion for a single AUV as a group agent.

Subject of research - the process of intelligent control of an autonomous underwater vehicle as a group agent.

The basic material. Modeling of marine robot navigations in coastal and marine environmental conditions, together with the suitable sensor data, is a basic requirement for the marine robotics community to develop effective control algorithms.

The use of fuzzy ACS-GT for these purposes requires only the use of a small number of local rules that relate the AUV required speed, as well as the angular deviation and angular speed of the AUV $[17 ; 18]$.

As shown in Fig. 1, the AUV initialization - task introduction of $\vec{X}_{g}\left\{v_{g}, \phi_{g}, h_{g}\right\}$ on the GT (where $v_{g}, \phi_{g}, h_{g}$ are the given speed of rectilinear motion, course and depth of immersion of the AUV respectively) and the GT mission completion duration survey and AUV location coordinates $\left\{\boldsymbol{T}_{G T} ;\left(\gamma_{c}, \lambda_{c}\right)\right\}$ (where $T_{G T}$ is the time spent in the mission, and $\gamma_{c}, \lambda_{c}$ are the AUV coordinates at time $T_{G T}$ ) at any time of the mission are the first step.

To assess the degree of collision threats between the AUVs group agents, it is proposed to introduce special blocks in the AUV components: a navigation situation model (NSM) around the corresponding AUV and a nav- igation threat identifier (NTI) that calculates the navigation threats for the AUV.

Data on the presence of other underwater vehicles of the group near the $i$-th AUA (bearing and distance to each of them) are measured by sensors and fed to the NSM block, which consists of ES and a derivative calculator (DC).

Here, sensors survey, software definition of the proximity (danger) of neighboring AUVs are carried out and displays the values of $v_{i}$ и $\phi_{i}$ of the $i$-th AUV, and then the ES survey is carried out sequentially for accurate navigation system and location determination, path tracking, guidance and control to ensure the coordinate determination according to the principle of distance dead reckoning $X$ and the derivatives $\left(\frac{d X}{d t}\right)$ calculation of the neighboring AUVs from the NSM output and the transmission of this information to the NTI.

The degree of danger of the identified navigation threat is determined in the NTI. GT operates under different $\mathrm{y}_{1}$ conditions as follows:

1) $x_{1}$ - here, the AUV is in normal conditions, i. e., when there are no neighboring AUVs located too close to cause threats, or too far from the operating range, which causes the communication loss. If the ES does not detect the neighboring AUV, the AUV ACS GT operates in the mode of stabilization of the motion parameters $\vec{X}_{3}$ . That is, the AUV ACS GT will try to fulfill the equality $\vec{X}(t)=\vec{X}_{3}$, where the vector $\vec{X}(t)=\{v, \phi, h\}$ consists of the current rectilinear motion speed $v$, course $\varphi$ and immersion depth $h$ of the AUV. Due to the fact that the paper considers the plane motion of AUVs, the control of immersion depth $h$ is not further considered;

2) $x_{2}$ - here, there the course error is sensed and the control signals $\phi_{i}$ и will be calculated on the actuator as to make any adjustments;

3) $x_{3}$ - here, also the speed error is sensed and the control signals $v_{i}$ will be calculated on the actuator as to know any adjustments to be made to the system;

4) $x_{4}$ - here, the simultaneous occurrence of course and speed errors are sensed and as a result the control signals $v_{i}$ and $\phi_{i}$ will be calculated on the actuator and the adjustments to be made to the system will be known;

5) $x_{5}$ - taking into account the neighboring AUVs, when the neighboring AUVs are sensed, the NTI is triggered and there will be threat warnings. The GT will adjust on the basis of the neighboring AUV position, which operates in two ways:

a) on condition $x_{6}$, when the neighboring AUV is in the working zone, but too close to the AUV (within the distance, in the danger zone), which can cause a collision. The fuzzy logic controller (FLC) describes the control protocol using "If-Then" rules, such as If the distance is very close to the AUV-neighbor. Signal will be sent to the ACS-GT which will work on the program, and feeds to the AUV system actuator (actuating mechanism), which controls the AUV propeller-steering complex (PSC) which ensures its movement in a given direction and maneuvers the AUV to move away from its neighbor's direction, to avoid collisions based on fuzzy rules. This process is called adhesion; 


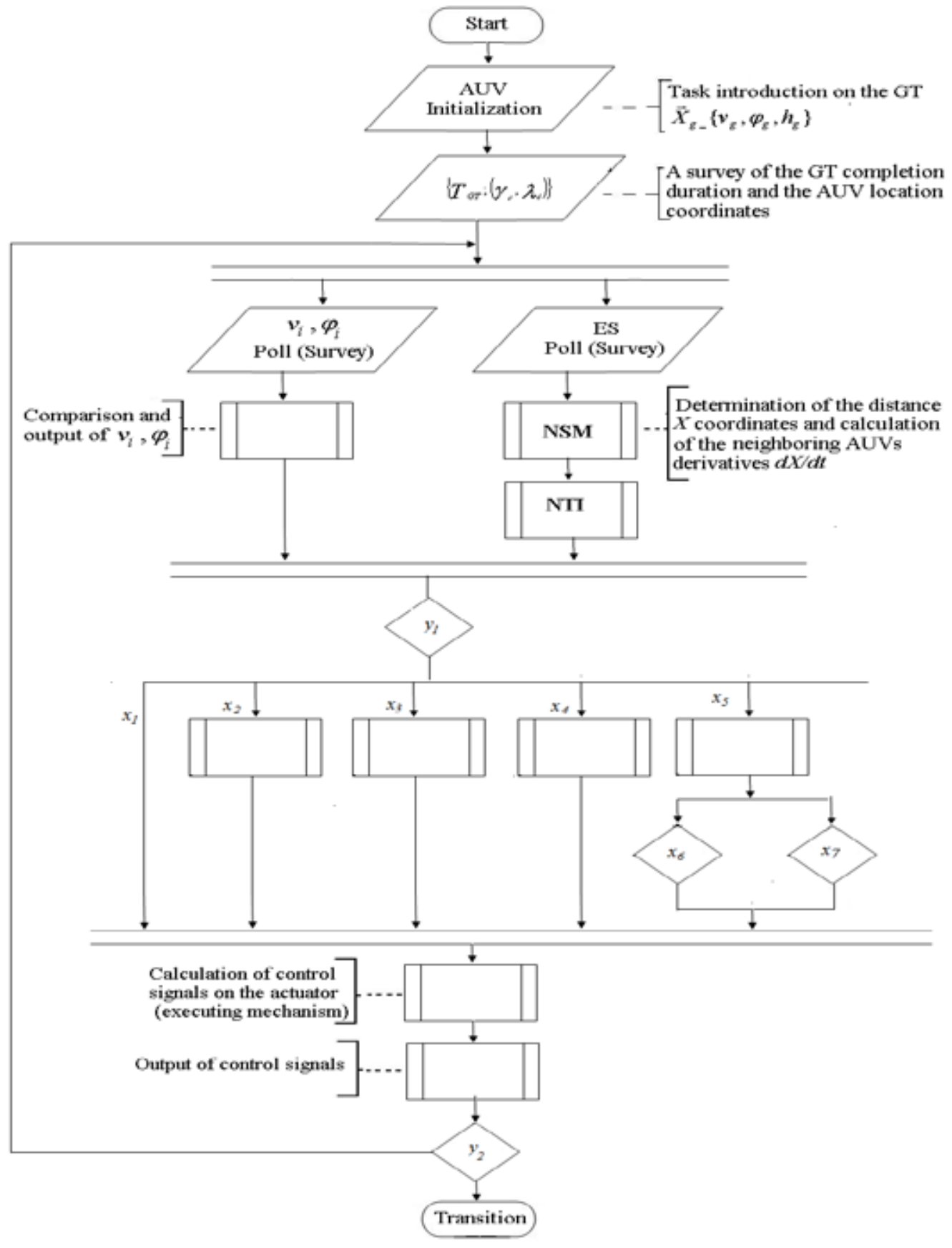

Fig. 1. A generalized operating algorithm for the automatic control system of a single AUV as an agent of a group of underwater vehicles

b) On condition $x_{7}$, when the neighboring AUV moves in the AUV working zone, but far from it, i. e. moving away from the working zone. The fuzzy controller system generates a control signal in accordance with the selected control algorithm in ACS-GT, which will work on the program, and then the AUV will approach (move closer to) the neighboring AUV to maintain the system wholeness so as not to lose the connection (communication) that will affect the group. This process is called cohesion.

There will be the control signals calculations of all the conditions and cases fed to the actuator, and then the output control signals.
There will be continuous data processing of the process after this eventually gets to condition $y_{2}$, if the AUV still has GT working hours $T_{G T}$, and performing tasks, the system cycle continues constantly, as above. The mission will be completed at the end of this GT working time $T_{G T}$, when the AUV will no longer perform any task.

To provide an example of a typical AUV scheme with respect to the neighboring AUVs in a specific mission, we assume that a team of robotic vehicles are deployed on a survey, track and search mission for sunken objects. Synthesis of intelligent automatic control system of one of the AUVs will be carried out as a group agent. In Fig. 2, the AUV1 is the research object (differs in colors from the 
other vehicles) and around it are the neighboring AUVs, which can cause threats to it, when too close, and to avoid a collision, it has to be maneuvered right or left, depending on which side any of the neighbors appear. The task is based on the sensor readings, it is necessary to evaluate where and from where the threats arise and evaluate not only statically but in dynamics.

Suppose that the vehicles are controlled only in the horizontal plane and the vertical motion maneuver is not present or is rarely used in an emergency when maneuvers in the plane are insufficient for the safe movement of the AUV and as a forced motion to avoid collisions with the neighboring AUVs.

The AUV (agent) is equipped with the navigation ES on the hull ( $S 1, S 2, S 3$ and $S 4)$ of the AUVs as seen in Fig. 2. Typically, the number of sensors varies within the limit of $n$, where $n \geq 4 \leq 12$ and provides the distance measurements between AUVs at the corresponding heading angles in the range from $0.1 \mathrm{~m}$ to $20 \mathrm{~m}$, which allows us to build an effective ACS-GT mode.

$S 1$ and $S 3$ are the ESs on the right and left side of the AUV hull while $S 2$, and $S 4$ are on the nose (head) and base of the AUV hull, respectively. Each ES senses, evaluates and determines the distances between the AUV (agent) and neighboring AUVs. For example, the $S 1$ sensor measures and detects neighboring AUVs on the right, and measures the distances between the AUVs and neighboring AUVs. Let $\mathrm{ab}\left(X_{11}\right)$ be the distance between the AUV and the neighboring AUVs. The distance between a and c (ac) is $X_{12}$ and the distance between a and $\mathrm{d}(\mathrm{ad})$ is $X_{13}$.

In cases where there are no neighbors in the range (operating range), the AUV tends to the maximum specified operating speed. These rules derived from the rules used to administer AUVs and can be summarized as follows.

When neighboring AUVs are detected within the range, the agent changes its speed and head angle, using information about the neighbor's distance, the neighbor's angle, and localization so as to avoid, and then recover from the obstacle. The agent must slow

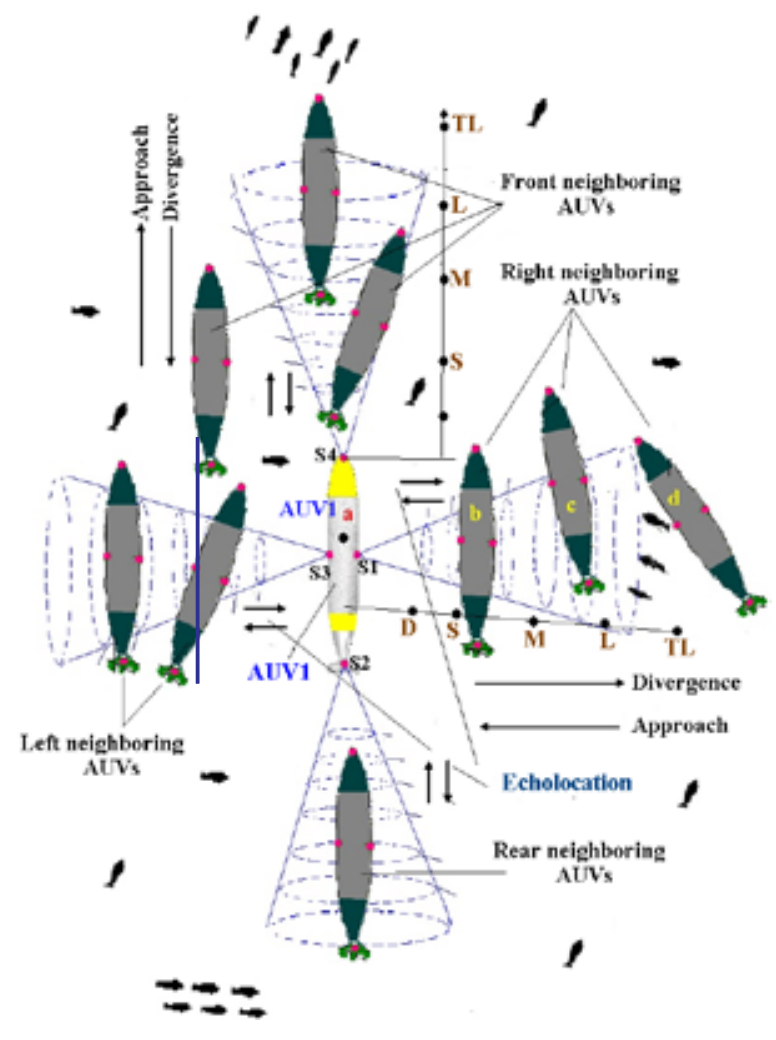

Fig. 2. Typical AUV scheme with respect to the neighboring AUVs in a specific mission

down and change course to avoid this. This turns the error control in the direction angle to approximately $90^{\circ}$. Once this is clear from this neighbor, it can continue on its path to the task. A set of rules that describes a change in the direction velocity and distance when a neighbor is detected, as can be summarized as in Table 1 and 2.

Another set of rules is for when the neighbors are at extreme distances and do not pose any collision threat. Under these conditions, AUV can head towards the neighbor, but at a reduced speed (to avoid making sharp turns to the neighbor). This is done so that the motion

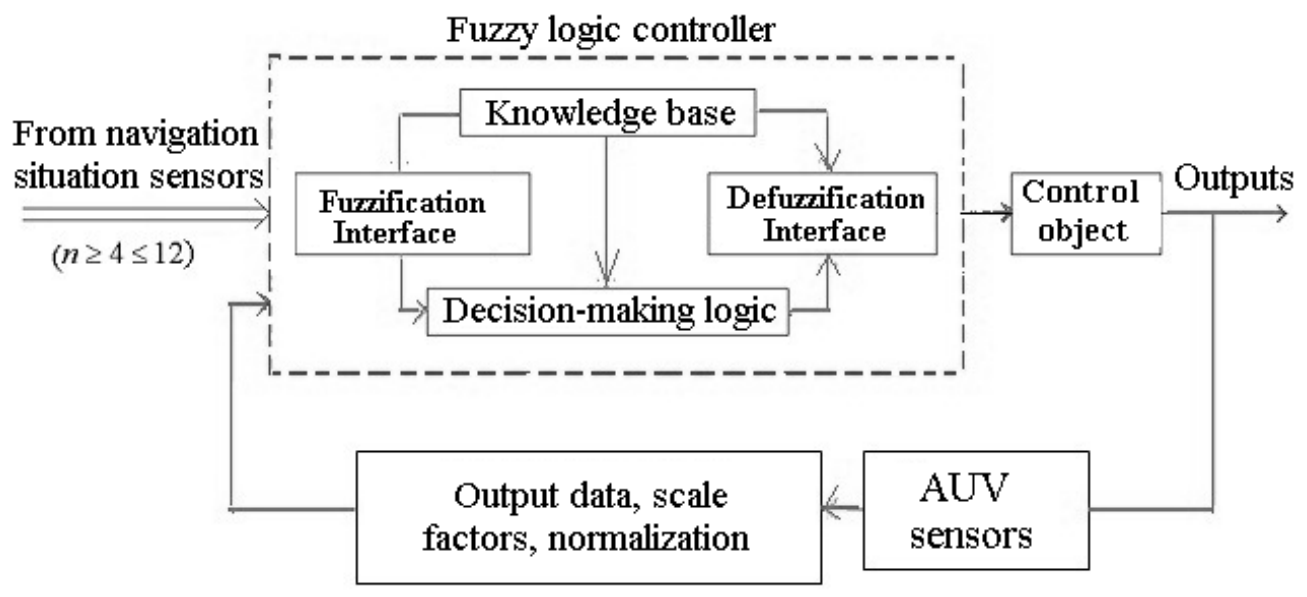

Fig. 3. AUV motion control system based on fuzzy logic 
planning along a given trajectory is a priority when the neighbors are not in the working zone, and collision avoidance is when they are in the working zone.

The main structure of the fuzzy controller is shown in Fig. 3. The closest of the neighboring AUVs shows the threat to the AUV and the AUV will, deal with it first and therefore ignore the others. The same applies to all detected neighbors on the left, nose and base or from any direction, that is, the signal in $S 1$ will be transmitted to the DC as can be seen in Fig. 4.

ES is also a criterion for the distance change coefficient $\left(\frac{d X_{11}}{d t}, \frac{d X_{21}}{d t}, \frac{d X_{31}}{d t}, \frac{d X_{41}}{d t}\right)$ relative to the AUV, which will give approaching and moving away from the neighbors.

If all the devices operate on a plane, where $x_{i}$ is the distance from the AUV to the neighbor by and large adjacent to the course $i ; x_{\min }$ is the minimum possible safe distance to the neighboring AUV, $x_{\max }$ is the the maximum allowable distance to the neighboring AUV:

An analysis of the AUVs group control tasks in the indicated phases of the marine mission execution indicates that one of the key tasks is to ensure the AUV safe (accident-free) motion in a group at a given depth $H_{G}$ with a given course $\varphi_{G}$ and with a given speed $v_{G}$. The theoretical basis for the automation of such an $A_{G}$ motion is the concept of $A_{G U}$ alignment, $A_{G A}$ adhesion and $A_{G C}$ cohesion.

The alignment concept provides for the tasks of three parameters of the AUVs group automatic motion:

$$
\begin{aligned}
& \text { alignment when } A_{G U}=\left\{\varphi_{G} ; v_{G} ; H_{G}\right\}, \\
& \text { adhesion when } A_{G A}=\left\{x_{i} \geq\left. x_{\min }\right|_{i=1, S}\right\}, \\
& \text { and cohesion when } A_{G C}=\left\{x_{i} \leq\left. x_{\max }\right|_{i=1, \ldots S}\right\} .
\end{aligned}
$$

Underwater ultrasonic, laser, or electronic and electrical sensors can be used as AUV rangefinders, which should provide the automatic control system of the underwater vehicle with sensitivity to neighboring AUVs moving in the group $[19 ; 20]$ :

$$
\begin{aligned}
& S 1 \Rightarrow \inf \left\{X_{11}, X_{12}, X_{13}, \ldots X_{1 n}\right\}=X_{11} \\
& S 2 \Rightarrow \inf \left\{X_{21}, X_{22}, X_{23}, \ldots X_{2 n}\right\}=X_{21} \\
& S 3 \Rightarrow \inf \left\{X_{31}, X_{32}, X_{33}, \ldots X_{3 n}\right\}=X_{31} \\
& S 2 \Rightarrow \inf \left\{X_{41}, X_{42}, X_{43}, \ldots X_{4 n}\right\}=X_{41}
\end{aligned}
$$

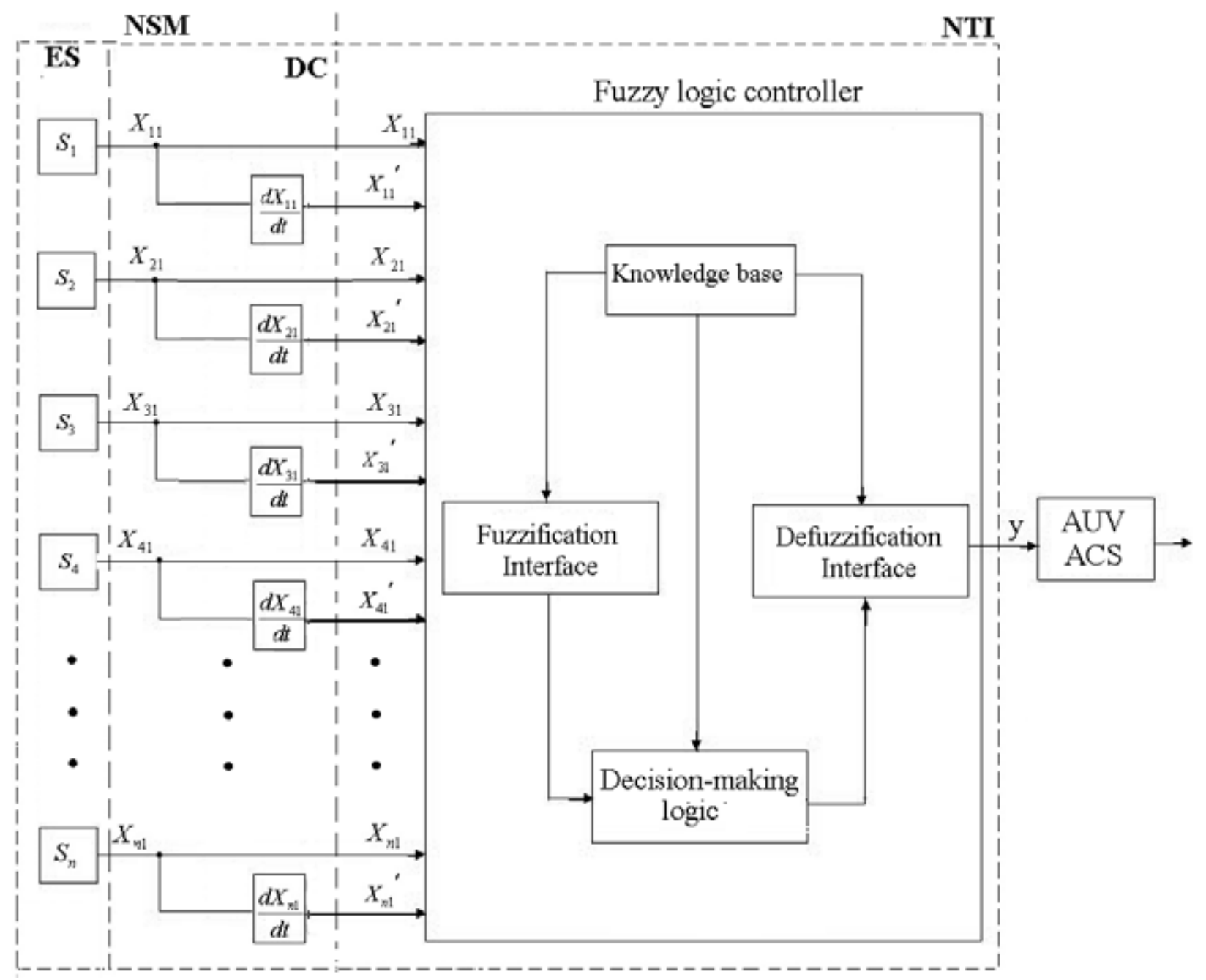

Fig. 4. The navigation situation modeling block of the AUV as a group agent: NSM - Navigation Situation Model; ES - environmental sensors; DC - module for derivative calculation; NTI - navigation threat identifier 
The NSM block will give a signal of the detected distance and derivatives in the NTI block, where there will be fuzzification for correction and send the AUV recommendation to maneuver to either avoid a collision or make it approach (move closer) to be in a group.

The NTI unit evaluates and calculates the navigational degrees of collision threats with the neighboring AUVs and/or the threat of contact loss with the AUVs group in the case of horizontal maneuver according to dependencies (1)-(3), and also calculates the forecast of the dynamics of the group of identified AUVs neighbors.

Linguistic variables used for the rate of change in the distance $(d X / d t)$ of the vehicle to or from the neighboring vehicle: TL - Threatening large; L - Large; M - Medium; S - Small; D - Dangerous.

Linguistic variables used for the distance between the AUV and the neighboring AUVs can be broken into: FA - Fast approach; MA - Medium approach;
SA - Small approach; Zero; FD - Fast divergence; MD - Medium divergence and SD - Small divergence. The AUV (agent) is equipped with sensors on the AUV hull as shown in Fig. 5.

Synthesis of the blocks is based on fuzzy logic system, which consists of accurate inputs, accurate outputs and fuzzy rules. A synthesis was proposed to determine the distances between the vehicles and the distance derivatives, thus tuning the system and maneuvering to avoid collisions between the neighboring AUVs during operations.

With the help of the ES, the AUV can detect neighbors that can cause collisions, as well as static and dynamic obstacles in the operating range. Sensors are very effective in dynamic conditions.

To calculate the fuzzy inference system, at a given input, it is necessary to go through the steps shown in Fig. 2.

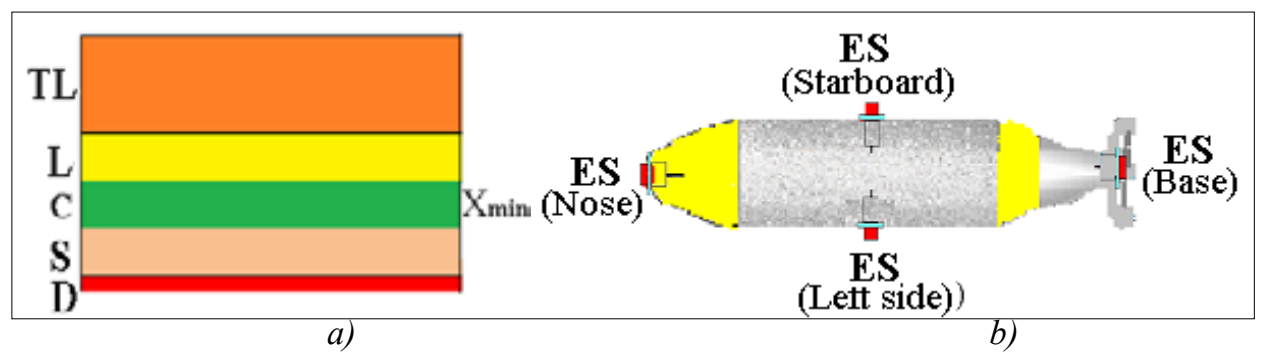

Fig. 5. Arrangement notes of linguistic variables and the arrangements of the navigation ESs on the AUV (agent) sides: a) AUV distances from neighboring AUVs; b) ES on AUVs sides with the amount of $n=4$, where $n \geq 4 \leq 12$

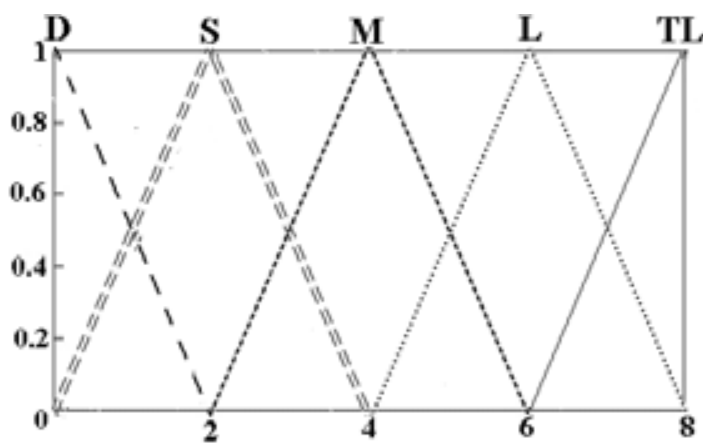

\begin{tabular}{|c|c|c|}
\hline TL & & $\begin{array}{c}\text { Threatening } \\
\text { large }\end{array}$ \\
\hline $\mathbf{L}$ & 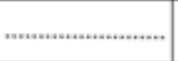 & Large \\
\hline $\mathbf{M}$ & ........ & Medium \\
\hline $\mathbf{S}$ & $==\pi===\pi$ & Small \\
\hline D & $----\cdots$ & Dangerous \\
\hline
\end{tabular}

a)

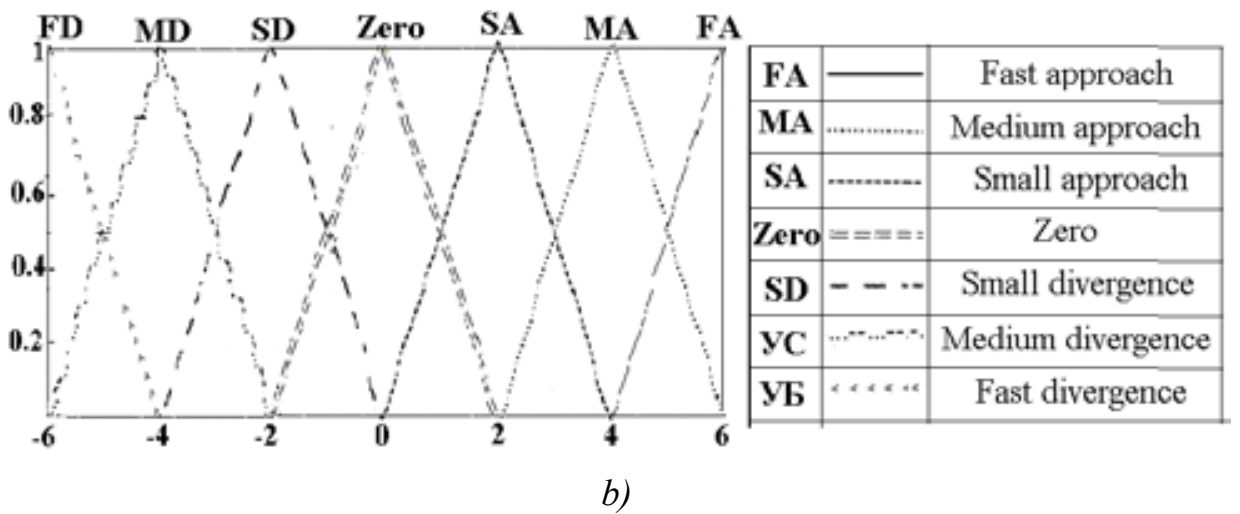

Fig. 6. Membership functions: $a$ ) input variable, «distance from a neighbor» precise values of distance sensors; $b$ ) input variable, «neighbor approach/divergence speed» precise values, $d x / d t$ 
Based on the membership functions for the input variable of the fuzzy logic controller for the distance and the rate of approach/divergence of a neighbor between the AUV and the neighboring AUVs are presented in (Fig. 6). For inputs and outputs, a series of rules based on empirical knowledge that describes the interaction between the inputs and outputs are indicated. This set of rules, which forms the basis of the fuzzy system rules, is shown in tables 1 and 2 .

From table 1, when the neighboring AUVs are in the TL with FA speed, on the right or left of the AUV, we get the RS ${ }^{\mathrm{MR}}\left(\mathrm{LS}^{\mathrm{ML}}\right)$, which means that it approaches the neighboring AUV with an average speed towards the neighbor (Right or Left) to keep the contact with it.

When AUV-neighbors are located in D (danger zone) with FA (Fast approach) on the right and left of AUV, we get $\mathrm{RS}^{\mathrm{FL}}\left(\mathrm{LS}^{\mathrm{FR}}\right)$ which means that it moves at fast speed (F) in the opposite direction of the neighbor to prevent a collision. The received recommendations of different rules are given in table 1.

$\mathrm{H}^{\mathrm{SF} \text { and } \mathrm{D}}$ - Slowly in front (side of the nose of the AUV) or decelerate (slow down). When neighboring AUVs are in FD and FA, the AUV will slow down, if the threat still exists, then the AUV will go left or right to avoid a collision. If it is impossible to maneuver to the sides, he will submerge to avoid a collision. This operation is not considered here, since we are dealing with the control of motion on a plane. The recommendations received are given in the table 2. Here we get $\mathrm{N}^{\mathrm{Z}, \mathrm{L} \text { or S }}$ (and dive if necessary, that is, $\mathrm{N}^{\mathrm{Z}, \mathrm{L} \text { or } \mathrm{S}}$ ). $\mathrm{K}^{\mathrm{DF} \text { or STOP }}-\mathrm{AUV}$ will decelerate (slow down) towards the nose of AUV or stop.
The output mechanism, based on the type of inference engine and rule bases, sends the output to the fuzzification block for conversion to a numerical value.

Discussion of the received results. AUVs are playing more and more roles with the development of artificial intelligence (AI). Multiple-AUVs work together to solve various types of tasks with the advantages of low cost, high adaptability and ease of maintenance compared to using one AUV for operations.

This work is aimed at developing useful AUV technology for ocean technology and extending the state of the art in intelligent control by synthesizing intelligent automatic control system with the ability to create and execute plans of action for easy and better implementation of accident-free underwater missions.

Group control of AUVs is challenging due to uncertainties in dynamics and communication constraints under environmental disturbances. For this reason, it is expedient to create an intelligent automatic control system that will make them navigate without colliding with each other or not getting too far from each other as not to lose the communication between the neighboring AUVs.

To tackle this issue, the composition and configuration of the system of ES which allows an AUV to identify the presence of neighbors in close proximity and the direction of their motion are proposed. The block "Navigation situation Model" and the block "Navigation threats Identifier", is also introduced into its intelligent ACS GT structure to exclude the threat of an emergency collision of the neighboring AUVs and control the dis-

Table 1. Fuzzy rules for neighbors' approach/divergence from the right and left sides (RS-Right side (starboard) and LS-Left side)

\begin{tabular}{|c|c|c|c|c|c|c|c|}
\hline$x_{x} d x / d t$ & FA & MA & SA & Zero & SD & MD & FD \\
\hline \multirow{2}{*}{$\mathrm{TL}$} & $\mathrm{RS}^{\mathrm{MR}}$ & $\mathrm{RS}^{\mathrm{FR}}$ & $\mathrm{RS}^{\mathrm{FR}}$ & $\mathrm{RS}^{\mathrm{FR}}$ & $\mathrm{RS}^{\mathrm{FR}}$ & $\mathrm{RS}^{\mathrm{MR}}$ & $\mathrm{RS}^{\mathrm{FR}}$ \\
\hline & $\mathrm{S}^{\mathrm{ML}}$ & $\mathrm{LS}^{\mathrm{FL}}$ & $\mathrm{LS}^{\mathrm{FL}}$ & $\mathrm{LS}^{\mathrm{FL}}$ & $\mathrm{LS}^{\mathrm{FL}}$ & $\mathrm{LS}^{\mathrm{ML}}$ & $\mathrm{LS}^{\mathrm{FL}}$ \\
\hline \multirow{2}{*}{$\mathrm{L}$} & $\mathrm{RS}^{\mathrm{FL}}$ & $\mathrm{RS}^{\mathrm{SL}}$ & $\mathrm{RS}^{\mathrm{ML}}$ & $\mathrm{RS}^{\mathrm{FL}}$ & $\mathrm{RS}^{\mathrm{ML}}$ & $\mathrm{RS}^{\mathrm{FL}}$ & $\mathrm{RS}^{\mathrm{FL}}$ \\
\hline & $\mathrm{LS}^{\mathrm{ML}}$ & $\mathrm{LS}^{\mathrm{ML}}$ & $\mathrm{LS}^{\mathrm{ML}}$ & $\mathrm{LS}^{\mathrm{FL}}$ & $\mathrm{LS}^{\mathrm{FL}}$ & $\mathrm{LS}^{\mathrm{FL}}$ & $\mathrm{LS}^{\mathrm{FL}}$ \\
\hline \multirow{2}{*}{ Medium } & $\mathrm{RS}^{\mathrm{FL}}$ & $\mathrm{RS}^{\mathrm{ML}}$ & $\mathrm{RS}^{\mathrm{SL}}$ & $\mathrm{RS}^{0}$ & $\mathrm{RS}^{\mathrm{SR}}$ & $\mathrm{RS}^{\mathrm{MR}}$ & $\mathrm{RS}^{\mathrm{FR}}$ \\
\hline & $\mathrm{LS}^{\mathrm{FR}}$ & $\mathrm{LS}^{\mathrm{MR}}$ & $\mathrm{LS}^{\mathrm{SL}}$ & $\mathrm{LS}^{0}$ & $\mathrm{LSS}^{\mathrm{L}}$ & $\mathrm{LS}^{\mathrm{ML}}$ & $\mathrm{LS}^{\mathrm{FL}}$ \\
\hline \multirow{2}{*}{ Small } & $\mathrm{RS}^{\mathrm{FL}}$ & $\mathrm{RS}^{\mathrm{SL}}$ & $\mathrm{RS}^{\mathrm{ML}}$ & $\mathrm{RS}^{\mathrm{SL}}$ & $\mathrm{RS}^{\mathrm{MR}}$ & $\mathrm{RS}^{\mathrm{MR}}$ & $\mathrm{RS}^{\mathrm{MF}}$ \\
\hline & $\mathrm{LS}^{\mathrm{FR}}$ & $\mathrm{LS}^{\mathrm{FR}}$ & $\mathrm{LS}^{\mathrm{MR}}$ & $\mathrm{LS}^{\mathrm{SR}}$ & $\mathrm{LS}^{\mathrm{ML}}$ & $\mathrm{LS}^{\mathrm{FL}}$ & $\mathrm{LS}^{\mathrm{FL}}$ \\
\hline \multirow{2}{*}{ D } & $\mathrm{RS}^{\mathrm{FL}}$ & $\mathrm{RS}^{\mathrm{FL}}$ & $\mathrm{RS}^{\mathrm{SL}}$ & $\mathrm{RS}^{\mathrm{SL}}$ & $\mathrm{RS}^{\mathrm{MR}}$ & $\mathrm{RS}^{\mathrm{SR}}$ & $\mathrm{RS}^{\mathrm{MF}}$ \\
\hline & $\mathrm{LS}^{\mathrm{FR}}$ & $\mathrm{LS}^{\mathrm{SR}}$ & $\mathrm{LS}^{\mathrm{MR}}$ & $\mathrm{LS}^{\mathrm{SR}}$ & $\mathrm{LS}^{\mathrm{ML}}$ & $\mathrm{LS}^{\mathrm{FL}}$ & $\mathrm{LS}^{\mathrm{FL}}$ \\
\hline
\end{tabular}

Table 2. Fuzzy rules for the approach/divergence rate of neighbors with the nose and base of the AUV (N-Nose, B-Base)

\begin{tabular}{|c|c|c|c|c|c|c|c|}
\hline $\mathrm{x}_{\mathrm{x}} \mathrm{dx} / \mathrm{dt}$ & FA & MA & SA & Zero & SD & MD & FD \\
\hline \multirow{2}{*}{$\mathrm{TL}$} & $\mathrm{N}^{\text {SF и D }}$ & $\mathrm{N}^{\mathrm{SF} \text { и D }}$ & $\mathrm{N}^{\mathrm{MF}}$ & $\mathrm{N}^{\mathrm{MF} \text { и } \mathrm{SF}}$ & $\mathrm{N}^{\mathrm{FF}}$ & $\mathrm{N}^{\mathrm{FF}}$ & $\mathrm{N}^{\mathrm{FF}}$ \\
\hline & $\mathrm{B}^{\mathrm{FF}}$ & $\mathrm{B}^{\mathrm{FF}}$ & $\mathrm{B}^{\mathrm{FF}}$ & $\mathrm{B}^{\mathrm{FF}}$ & $\mathrm{B}^{\mathrm{FF}}$ & $\mathrm{B}^{\mathrm{FF}}$ & $\mathrm{B}^{\mathrm{FF}}$ \\
\hline \multirow{2}{*}{$\mathrm{L}$} & $\mathrm{N}^{\mathrm{D}, \mathrm{L} \text { or } \mathrm{D}}$ & $\mathrm{N}^{\mathrm{D}, \mathrm{L} \text { or } \mathrm{D}}$ & $\mathrm{N}^{\mathrm{D}, \mathrm{L} \text { or } \mathrm{D}}$ & $\mathrm{N}^{\mathrm{FF}}$ & $\mathrm{N}^{\mathrm{FF}}$ & $\mathrm{N}^{\mathrm{FF}}$ & $\mathrm{N}^{\mathrm{FF}}$ \\
\hline & $\mathrm{B}^{\mathrm{FF}}$ & $\mathrm{B}^{\mathrm{FF}}$ & $\mathrm{B}^{\mathrm{FF}}$ & $\mathrm{B}^{\mathrm{FF}}$ & $\mathrm{B}^{\mathrm{FF}}$ & $\mathrm{B}^{\mathrm{FF}}$ & $\mathrm{B}^{\mathrm{FF}}$ \\
\hline \multirow{2}{*}{ Medium } & $\mathrm{N}^{\mathrm{D}, \mathrm{L} \text { or } \mathrm{D}}$ & $\mathrm{N}^{\mathrm{D}, \mathrm{L} \text { or } \mathrm{D}}$ & $\mathrm{N}^{\mathrm{D}, \mathrm{L} \text { or } \mathrm{D}}$ & $\mathrm{N}^{0}$ & $\mathrm{~N}^{\mathrm{SF}}$ & $\mathrm{N}^{\mathrm{MF}}$ & $\mathrm{N}^{\mathrm{FF}}$ \\
\hline & $\mathrm{B}^{\mathrm{FF}}$ & $\mathrm{B}^{\mathrm{MF}}$ & $\mathrm{B}^{\mathrm{SF}}$ & $\mathrm{B}^{0}$ & $\mathrm{~B}^{\mathrm{DF} \text { or STOP }}$ & $\mathrm{B}^{\mathrm{DF} \text { or STOP }}$ & $\mathrm{B}^{\mathrm{DF} \text { or STOP }}$ \\
\hline \multirow{2}{*}{ Small } & $\mathrm{N}^{\mathrm{D}, \mathrm{L} \text { or } \mathrm{D}}$ & $\mathrm{N}^{\mathrm{D}, \mathrm{L} \text { or } \mathrm{D}}$ & $\mathrm{N}^{\mathrm{D}, \mathrm{L} \text { or } \mathrm{D}}$ & $\mathrm{N}^{\mathrm{SF}}$ & $\mathrm{N}^{\mathrm{MF}}$ & $\mathrm{N}^{\mathrm{FF}}$ & $\mathrm{N}^{\mathrm{FF}}$ \\
\hline & $\mathrm{B}^{\mathrm{FF}}$ & $\mathrm{B}^{\mathrm{FF}}$ & $\mathrm{B}^{\mathrm{MF}}$ & $\mathrm{B}^{\mathrm{SF}}$ & $\mathrm{B}^{\mathrm{DF} \text { or STOP }}$ & $\mathrm{B}^{\mathrm{DF} \text { or STOP }}$ & $\mathrm{B}^{\mathrm{DF} \text { or STOP }}$ \\
\hline \multirow{2}{*}{$\mathrm{D}$} & $\mathrm{N}^{\mathrm{D}, \mathrm{L} \text { or } \mathrm{D}}$ & $\mathrm{N}^{\mathrm{D}, \mathrm{L} \text { or } \mathrm{D}}$ & $\mathrm{N}^{\mathrm{D}, \mathrm{L} \text { or } \mathrm{D}}$ & $\mathrm{N}^{\mathrm{DF} \text { and } \mathrm{MF}}$ & $\mathrm{N}^{\mathrm{MF}}$ & $\mathrm{H}^{\mathrm{FF}}$ & $\mathrm{N}^{\mathrm{FF}}$ \\
\hline & $\mathrm{B}^{\mathrm{FF}}$ & $\mathrm{B}^{\mathrm{FF}}$ & $\mathrm{B}^{\mathrm{MF}}$ & $\mathrm{B}^{\mathrm{SF}}$ & $\mathrm{B}^{\mathrm{DF} \text { or STOP }}$ & $\mathrm{B}^{\mathrm{DF} \text { or STOP }}$ & $\mathrm{B}^{\mathrm{DF} \text { or STOP }}$ \\
\hline
\end{tabular}


tances between them for maintaining the communication between the AUV,

The intelligent system provides stabilization of the speed of the vehicle spatial motion, the course and depth of its immersion (here the depth control is no looked into but it can be only needed for accident events!), and implements the adhesion and cohesion algorithms to ensure the coordinated motion of the neighboring AUVs.

The intelligent automatic control system in the group transition mode is based on the principle of coordinated control with the help of fuzzy logic system. The implementation of the fuzzy logic controller in Simulink is tested and presented on other scientific article. To get a better result with using the fuzzy logic control (FLC), the mapping of membership function can be tuned and also number of rules can be adjusted. The results make it clear that the robustness of FLC is better than PID control by comparison.

The quality of control processes can be improved by employing more advanced underwater distance sensors and optimizing the parameters of the ACS GT for robustness of AUVs coordinated spatial motion.

CONCLUSIONS. One of the main navigation problems of the AUV group is a collision with neighboring vehicles due to the uncertainty that arises during navigation. In the article, a highly effective adaptive intelligent ACS GT is synthesized for the motion of a single AUV, as an agent of a group of underwater vehicles making group transitions.

A generalized operating algorithm for the automatic control system of a single AUV as an agent of a group of underwater vehicles is compiled.

For the first time, the navigation situation simulation block is synthesized for a single AUV (agent) consisting of three blocks - the Navigation Situation Model block, the Navigation Threat Identifier block, and the automatic control system block in the group transition mode (ACS GT) for a single AUV built on the basis of fuzzy logic. The system blocks work on a program for the implementation of the AUVs accident-free coordinated motion in the group.

For the first time, a generalized algorithm for the automatic motion control of a single AUV in the group transition mode based on a fuzzy logic system has been synthesized. The ACS GT provides stabilization of the rectilinear speed and the course of the AUV, and also implements navigation processes with alignment, adhesion and cohesion to ensure AUVs coordinated motion in the group.

The fuzzy logic controller can be implemented on homogenous or heterogeneous AUVs groups for efficient operations with coordinated motion. The implementation of the fuzzy logic controller in Simulink is tested and presented as can be seen in article [21].

\section{List of literature:}

[1] Ioseba, Tena (2018). The Advancing Technology of AUVs. A View of the Autonomous Underwater Vehicle Market. Hydro International. Retrieved from https:/www.hydro-international.com/content/article/the-advancing-technologyof-auvs.

[2] Slămnoiu, G., Radu, O., Roşca, V., Pascu, C., Surdu, G., Curcă, E., Damian, R. G. \& Rădulescu, A. (2017). Efficient Use of AUVs in the Maritime Environment. International Conference on Innovative Research-Icir Euroinvent. Retrieved from http://iopscience.iop.org/article/10.1088/1757-899X/209/1/012098/pdf.

[3] Yeun-Soo, Jung, Kong-Woo, Lee, Seong-Yong, Lee, Myoung, Hwan \& Choi Beom-Hee, Lee (2009). An efficient underwater coverage method for multi-AUV with sea current disturbances. International Journal of Control, Automation and Systems, Vol. 7, 4, 615-629. Retrieved from https://link.springer.com/article/10.1007/s12555-009-0412-4.

[4] Zereik, Enrica, Bibuli, Marco, Miskovic, Nikola, \& Ridao, Pere (2018). Challenges and future trends in marine robotics. Annual Reviews in Control, 1-19. doi: 10.1016/j.arcontrol.2018.10.002. Retrieved from https://www.researchgate.net/publication/328255241_Challenges_and_future_trends_in_marine_robotics.

[5] Fiorelli, E, Leonard, N. E., \& Bhatta, P. (2006). Multi-AUV control and adaptive sampling in Monterey Bay. IEEE Journal of Oceanic Engineering, 31 (4), 935-948.

[6] Yoon, S., \& Qiao, C. M. (2011). Cooperative Search and Survey Using Autonomous Underwater Vehicles. IEEE Transactions on Parallel and Distributed Systems, 22 (3), 364-379.

[7] Dapeng, Jiang, \& Bin, He (2014). Realistic Cooperative Control Mechanism of Multiple AUVs. Proceedings of the 33rd Chinese Control Conference / July 28-30, 2014, 1395-1400.

[8] Benjamin, Michael R., Schmidt, Henrik, Newman, Paul M., \& Leonard, John J. (2010). Nested Autonomy for Unmanned Marine Vehicles with MOOS-IvP. Retrieved from http://140.117.95.8/teacher/PUB/conference/Abstract_ Schmidt.pdf.

[9] Rohou, Simon (2016). An Overview of the MOOS-IvP Middleware. Abstract for the SHARC conference, 1-7.

[10] Bikramaditya, Das, Bidyadhar, Subudhi \& Bibhuti, Bhusan Pati (2016). Co-operative control of a team of autonomous underwater vehicles in an obstacle-rich environment. Journal of marine engineering \& technology, Vol. 15, 3, 135-151. https://doi.org/10.1080/20464177.2016.1247636.

[11] Omrane, Hajer, Masmoudi, Mohamed Slim, \& Masmoud, Mohamed (2016). Fuzzy Logic Based Control for Autonomous Mobile Robot Navigation. http://dx.doi.org/10.1155/2016/9548482.

[12] Almasri, Marwah, Elleithy, Khaled, \& Alajlan, Abrar (2016). Sensor Fusion Based Model for Collision Free Mobile Robot Navigation. Sensors (Basel), 24. DOI: 10.3390/s16010024. Retrieved from http://www.mdpi.com/1424$8220 / 16 / 1 / 24$. 
[13] Elmokadem, Taha, Zribi, Mohamed, \& Youcef-Toumi, Kamal (2017). Terminal sliding mode control for the trajectory tracking of underactuated. Autonomous Underwater Vehicles, Vol. 129, 1 January 2017, 613-625. https://doi. org/10.1016/j.oceaneng.2016.10.032.

[14] Hai, Huang, Guocheng, Zhang, Hongde, Qing, \& Zexing, Zhou (2017). Autonomous underwater vehicle precise motion control for target following with model uncertainty. International Journal of Advanced Robotic Systems, 1-11. DOI: $10.1177 / 1729881417719808$.

[15] Omrane, Hajer, Masmoudi, Mohamed Slim, \& Masmoudi, Mohamed (2016). Fuzzy Logic Based Control for Autonomous Mobile Robot Navigation. Comput Intell Neurosci, 1-10. Retrieved from https://www.ncbi.nlm.nih.gov/ pmc/articles/PMC5027372/.

[16] Pandeya, Anish, Kumarb, Saroj, Pandeya, Krishna Kant, \& Parhia, Dayal R. (2016). Mobile robot navigation in unknown static environments using ANFIS controller. Perspectives in Science, 8, 421-423. Retrieved from https:// core.ac.uk/download/pdf/81931273.pdf.

[17] Distance Keeping for Underwater Vehicles - Tuning Kalman Filters Using Self-Oscillations. Retrieved from https://bib.irb.hr/datoteka/412520.Miskovic_et_al_OCEANS09_final_paper.pdf.

[18] Cain, C., \& Leonessa, A. (2016). Validation of Underwater Sensor Package Using Feature Based SLAM. Sensors, 16 (3), 1-29. https://doi.org/10.3390/s16030380.

[19] Algabri, M., Mathkour, H., Ramdane, H., \& Alsulaiman, M. (2015). Comparative Study of Soft Computing Techniques for Mobile Robot Navigation in an Unknown Environment. Computers in Human Behavior, 50, 42-56. Retrieved from https://dl.acm.org/citation.cfm?id=2798785.

[20] Omrane, H., Masmoudi, M. S., \& Masmoudi, M. (2016). Fuzzy logic based control for autonomous mobile robot navigation. Computational Intelligence and Neuroscience, 1-10. DOI:10.1155/2016/9548482.

[21] Burunina, Zhanna Yu., Aloba, Leo T., \& Hrudinina, Hanna S. (2018). Mathematical modeling of the automatic control system for an autonomous underwater vehicle as a group agent. Shipbuilding and Marine Infrastructure, 1 (9), 29-35. Retrieved from http://smi.nuos.mk.ua/article/view/142677/140183.

(c) Алоба Лео Тосин 